\title{
Self-Ownership and the Limits of Libertarianism
}

\section{Introduction}

In the longstanding debate between liberals and libertarians ${ }^{1}$ over the morality of redistributive labor taxation, liberals such as John Rawls and Ronald Dworkin have consistently taken the position that such taxation is perfectly compatible with individual liberty, ${ }^{2}$ whereas libertarians such as Robert Nozick and Murray Rothbard have adopted the (very) contrary position that such taxation is tantamount to slavery. ${ }^{3}$ I will demonstrate over the course of this paper that their debate over redistributive labor taxation can be usefully reconstituted as a debate over the incidents (or components) of self-ownership, with liberals making the case for a nar-

${ }^{1}$ I use the term liberal as a shorthand for liberal egalitarian throughout the paper. I define libertarians as a type of classical liberal, distinguished from other classical liberals by their extreme positions on personal liberty issues and by their style of political theorizing, which is characterized by the rigorous deduction of political positions from first principles such as self-ownership. Libertarians may be further subdivided into right-libertarians (such as the Robert Nozick of Anarchy, State, and Utopia and Murray Rothbard), who oppose any form of redistribution, and left-libertarians (such as Hillel Steiner, Michael Otsuka, and Peter Vallentyne), who support the redistribution of natural resources but generally oppose redistributive labor taxation. For more information on left-libertarianism, see Peter Vallentyne and Hillel Steiner (eds.), The Origins of Left Libertarianism: An Anthology of Historical Writings (New York: Palgrave Publishers, 2000) and Left Libertarianism and Its Critics: The Contemporary Debate (New York: Palgrave Publishers, 2000).

${ }^{2}$ Rawls, for example, considers the Equal Liberty Principle to be lexically prior to the Difference Principle, despite the latter's implications for redistributive labor taxation; see A Theory of Justice, 1st ed. (Cambridge, Mass.: Harvard University Press, 1971), pp. 302-3. Dworkin, it is true, suggests that very high taxes on the earnings of the talented might be analogous to slavery, but as I will show later in the paper, it is certain forms, not levels, of taxation that compel labor in a manner that resembles slavery. Dworkin makes his claim in "What is Equality? Part 2: Equality of Resources," Philosophy and Public Affairs 10 (1981): 283-345, p. 322.

${ }^{3}$ As Nozick says in Anarchy, State, and Utopia (New York: Basic Books, 1974), p. 169, "taxation of earnings from labor is on a par with forced labor." Similarly, Rothbard argues that "the entire system of taxation is a form of involuntary servitude ... Part of the essence of slavery, after all, is being forced to work for someone at little or no pay" (For a New Liberty: The Libertarian Manifesto (New York: Libertarian Review Foundation, 1973), p. 85). 
row definition of the concept and libertarians arguing for a broad one. By using what Alan Ryan has called the "language of proprietorship," we will be able to pinpoint the source of their disagreement and to assess the relative strengths of their arguments. ${ }^{4}$ We will also discover that the respective definitions of self-ownership used by liberals and libertarians are deeply problematic - though for entirely different reasons.

In section 2, I will review the potential incidents of ownership in general, focusing on two major classes: the control rights and the right to income. I will offer a minimalist definition of self-ownership consisting of these control rights (called, appropriately enough, "control self-ownership" or "CSO") and will also show that control rights do not directly imply a right to income, a result that greatly complicates libertarian efforts to argue against redistributive labor taxation. In section 3 , I will construct model liberal and libertarian definitions of self-ownership using the incidents discussed in the previous section and will also determine whether any architectonic principles exist to justify the configurations of incidents contained in these definitions. As we shall see, libertarians face a difficult, perhaps insuperable, challenge in getting the various elements of their conception of self-ownership (namely, the control rights and the right to income) to cohere, whereas liberals face the very different challenge of integrating a coherent conception of self-ownership (namely, CSO) into an ideological environment that may be inhospitable to it.

\section{The Potential Incidents of Ownership}

\section{a. The control rights}

Ownership is commonly conceived as a bundle of rights, liberties, powers, immunities, and so on. A.M. Honoré, in his influential essay on this subject, lists no fewer than eleven "standard incidents," or constituent elements, of ownership. ${ }^{5}$ Some of these incidents, however, are more essential than others, as Honoré notes: "no doubt the concentration in the same person of the right ... of using as one wishes, the right to exclude others, the power of alienating and an immunity from expropriation is a cardinal feature of the institution [of ownership]." dents - the rights of use and exclusion, the power of transfer, and an im-

\footnotetext{
${ }^{4}$ Alan Ryan, "Self-Ownership, Autonomy, and Property Rights," Social Philosophy and Policy 11 (1994): 241-58, p. 249.

${ }^{5}$ A.M. Honoré, "Ownership," in A.G. Guest (ed.), Oxford Essays on Jurisprudence (Oxford: Oxford University Press, 1961), pp. 108-34.

${ }^{6}$ Ibid., p. 113.
} 
munity from expropriation-may be termed "control incidents" or, more loosely, "control rights." To have control rights over an object is to possess final authority regarding the disposition of that object and to be free from interference in the exercise of that authority-unless, of course, the rights of others are being threatened. It is in effect to enjoy a kind of sovereignty over the owned object vis-à-vis other citizens.

These control rights are very closely related to one another, not just because they jointly protect managerial authority over the owned object but also because the right of exclusion plays a central justificatory role with respect to the other incidents. The right of use, for example, can be thought of as a temporary right of exclusion contingent upon use (as when one claims a place in an open-seating event). Understood in this way, the right of exclusion simply implies the right of use: a permanent right of exclusion by definition includes a temporary right of exclusion. ${ }^{7}$ The right of exclusion does not imply a power of transfer, but it comes close: an owner can effectively transfer his property to another party by making a binding promise to exercise his own exclusion rights as the second party directs (e.g., excluding third parties as requested by the second party). Strictly speaking, however, a transfer has only been simulated in this case, as third parties still owe their duties of noninterference to the original owner, not to the second party. The power of transfer thus goes beyond the right of exclusion by placing the second party in the position of the original owner, that is, by changing the underlying structure of duties. Finally, an immunity from expropriation is essentially a higher-order right of exclusion: it excludes state efforts to override existing rights of exclusion through the exercise of (political) power. ${ }^{8}$

These control rights or incidents offer a compact and coherent conception of ownership, one centered around the right of exclusion and protective of owners' sovereignty over property; though rudimentary, it includes all of what Honoré calls the "cardinal feature[s]" of ownership. As applied to the ownership of the self, this conception yields a version of self-ownership that has been called "control self-ownership," or simply "CSO," in the literature. ${ }^{9}$ Specifically:

\footnotetext{
${ }^{7}$ The right of use can also be conceived as a liberty right rather than a claim right (against others). If so, the right of use will not necessarily follow from the right of exclusion. For example, a trustee may have a right to exclude others from using a resource though he is not at liberty to use it himself.

${ }^{8}$ Many thanks to Peter Vallentyne for comments and suggestions on the material in this paragraph.

"The term "control self-ownership" is originally from John Christman, The Myth of Property: Toward an Egalitarian Theory of Ownership (Oxford: Oxford University Press, 1994), p. 160. He developed the conception itself in an earlier work, however: see "Self-Ownership, Equality, and the Structure of Property Rights," Political Theory 19 (1991): 28-46.
} 
Control self-ownership (CSO) consists of the rights of use and exclusion, the power of transfer, and an immunity from expropriation with respect to one's own body and labor power, with these incidents being held permanently and in rem (i.e., against the world).

I will show in section 3 that CSO serves as the core of liberal and libertarian conceptions of self-ownership; the two conceptions differ, however, over whether to include a right to (labor) income.

\section{b. The right to income}

Determining the meaning of a right to income is a surprisingly challenging task. This right figures prominently in libertarian arguments against redistributive labor taxation, as we shall later see, and Honore counts it among the standard incidents of the "liberal concept of ownership." It meaning is not immediately obvious, however, so we will proceed by considering several alternative definitions of it.

One rather direct interpretation of the right to income would be that it guarantees the owner a specific sum of money. This right might or might not be contingent upon an actual economic exchange taking place. Clearly, any such right would imply a duty on the part of (unspecified?) others to transfer money to the owner. A number of reasons militate against the adoption of this direct approach, though. First, as John Christman has noted, such a right seems to be of a type fundamentally different from that of the control rights discussed above:

The other elements of ownership can be understood to be held in rem (against everyone): They imply a duty on everyone's part not to interfere with my possession and use of the resource. But the right to the income cannot be considered in this way, for no one has a duty to supply me with income. ${ }^{11}$

We would like to find a definition of the right to income that fits well into the system of control rights that we have already developed. A second, related point is that positive rights such as the proposed right to income are difficult to fit into any system of compossible rights, owing to their tendency to conflict with other rights in the system (e.g., rights of exclusion and/or other rights of income). ${ }^{12}$ Finally, the proposed right to income is inherently vague, and leads to a host of puzzling questions

\footnotetext{
${ }^{10}$ Honoré, "Ownership," pp. 108, 117-18.

${ }^{11}$ Christman, "Self-Ownership, Equality, and the Structure of Property Rights," p. 33.

${ }^{12}$ This tension between the positive right to income and the negative right to noninterference in property ownership is illustrated by Robert Nozick's famous "Wilt Chamberlain" example in Anarchy, State, and Utopia, pp. 160-64.
} 
about the specific level of income to be provided and the identity of those persons obligated to provide it.

An alternative approach to defining a right to income is to think about this right as being a direct implication of a seller's power of transfer. After all, if the seller has the power to transfer a product, service, or factor to a buyer, then does he not as a necessary consequence have a right to the fruit of that transfer, that is, to the price (income) paid by the buyer? The answer, somewhat surprisingly, is no. The price that a seller receives in an economic exchange is, strictly speaking, independent of his power of transfer; rather, it is dependent on the buyer's power of transfer.

A simple example will demonstrate this point. Imagine two parties who wish to engage in an economic exchange: Andy, a seller of labor (i.e., a potential employee), and Betty, a buyer of labor (i.e., a potential employer). Andy agrees to transfer to Betty one hour of his labor, and Betty in return agrees to transfer to Andy ten dollars. Andy then proceeds to work one hour for Betty, fulfilling his self-imposed obligation of labor. As Betty is in the process of handing ten crisp one-dollar bills to Andy, thus fulfilling her self-imposed monetary obligation, the rapacious warlord Charles (attracted by the smell of fresh cash) sweeps down from the hills on his trusty steed Dancer and pilfers two of these bills from her. Betty, temporarily stunned by this unexpected loss, quickly recovers her wits and attempts to "renegotiate" her purchase price. Andy, his lungs irritated by horse dander and his muscles aching from an hour of hard labor, replies brusquely that "a promise is a promise," and Betty is obliged to replace the two missing bills with another two out of her own pocket.

Whose power is interfered with here? The answer is clearly Betty's power. When Betty attempted to hand the ten one-dollar bills to Andy, the warlord Charles seized two bills, thereby interfering with Betty's power of transfer. Andy's power of transfer, on the other hand, is unaffected: Betty became the rightful owner of one hour of Andy's labor, just as Andy had promised. Some readers will suspect, however, that the example has been rigged. After all, Andy ends up getting exactly what he was promised - ten dollars - so on what grounds could he possibly complain? "What," the suspicious reader might ask, "would happen if both Andy and Betty knew in advance about Charles's sharp nose for cash and his penchant for pilfering two dollars?"

Well, let us find out. If both Andy and Betty were aware of Charles's modus operandi, Betty would likely be in a position to negotiate a lower wage rate, thus forcing Andy to bear some of the burden of Charles's uncouth behavior. ${ }^{13}$ Suppose that this newly negotiated net wage rate

\footnotetext{
${ }^{13}$ Under what conditions will this statement be true? Suppose that Andy and Betty's
} 
would be nine, rather than ten, dollars. Andy would therefore agree to transfer to Betty one hour of his labor, just as before, and Betty would in return agree to transfer to Andy a mere nine dollars. Andy would then proceed to work one hour for Betty, fulfilling his self-imposed obligation of labor. Betty, prepared this time for Charles, would hand Andy eleven one-dollar bills to fulfill her self-imposed monetary obligation. Charles and Dancer would seize two of these dollar bills from Betty, leaving Andy with nine dollars, as was promised.

Would anything change as a result of Andy and Betty's foreknowledge of Charles and Dancer's descent from the hills? The burden of theft would certainly be distributed differently: it would now be evenly split between Andy and Betty. Notice, however, that Betty's power would still be the only one affected: Betty's attempt to transfer the eleven one-dollar bills to Andy would be interrupted by the warlord Charles's seizure of two bills, which would interfere with Betty's power of transfer. Andy's power of transfer, on the other hand, would once again be unaffected: Betty would became the rightful owner of one hour of Andy's labor, just as Andy had promised. So, we are once again driven to the conclusion that the seller's power of transfer does not directly imply a right to the income derived from that transfer.

So far it would seem that little progress has been made - but we have, in fact, already stumbled upon the solution: the seller's right to income is directly implied by the buyer's power of monetary transfer. In other words, all that a seller needs to have a secure right to the income from the sale of some item is the protection of the power of potential buyers to transfer money to him. ${ }^{14}$ To paraphrase (badly) a popular bumper-sticker,

economic exchange is embedded in a competitive labor market, i.e., there are a large number of potential buyers and sellers of Andy's grade of labor. In this case, negotiations between Andy and Betty over wage rates will be perfectly constrained: Betty will have to pay, and Andy will have to accept, the competitive wage rate. Within this framework, let us now consider the effect of Charles's behavior, which is exactly like the imposition on buyers of a two-dollar tax per labor hour purchased (a tax referred to in public finance as a "unit tax"). Economic theory suggests that the economic incidence of the tax (i.e., how the tax burden is ultimately divided between buyer and seller) will be a function of the wage elasticities of supply and demand. Generally, both seller and buyer-both Andy and Betty-will share in the tax burden. The only circumstances under which Andy and other sellers will be able to avoid bearing any of the burden of Charles's larceny are if demand is perfectly wage-inelastic and/or if supply is perfectly wage-elastic. Neither of these circumstances seems particularly likely. See Harvey Rosen, Public Finance (Homewood, Ill.: Richard D. Irwin, Inc., 1985), pp. 243-49, for a more detailed explanation.

${ }^{14}$ Careful readers will notice that the truth of this statement hinges on the nature of the unit taxes imposed on such transactions. If unit taxes were imposed on the seller as well as the buyer, then the above statement would have to be modified slightly. Specifically, it would need to have the following phrase appended to it: "and the protection of 
"a threat to powers of monetary transfer anywhere is a threat to rights of income everywhere." Once this relation is recognized, Jeremy Waldron's assertion that "there is no sense to the idea that there is a natural phenomenon called 'reaping the benefits of one's talents' which is understood apart from the social arrangements and institutions that define one's relationships to other people" becomes more intelligible. ${ }^{15}$

We have examined a variety of potential incidents of ownership in this section, including the rights of use, exclusion, and income, the power of transfer, and immunity from expropriation. Notice that the right to income is the odd man out: the right of use, the power of transfer, and an immunity from expropriation form a coherent grouping with the right of exclusion (which serves a justificatory role for them), while the right to income stands apart due to its derivation from an entirely different sourcenamely, the (monetary) transfer powers of other people. As we shall see shortly, this cleavage between control rights and a right to income is implicitly exploited by liberals in their ongoing debate with libertarians over the meaning of self-ownership and its implications for redistribution.

\section{Liberal and Libertarian Conceptions of Self-Ownership}

\section{a. The basic conception: control self-ownership}

Control self-ownership (CSO) constitutes the core of the libertarian conception of self-ownership. It has a host of radical implications for personal liberty issues, implications that are decidedly libertarian in flavor. First, CSO directly implies that individuals may sell their entire bodies (e.g., voluntary slavery or indentured servitude) or parts of their bodies (e.g., kidneys for transplant operations), though they are not necessarily

the control rights of the seller over that money." The reason that I am not bothering to make this adjustment in the text is that the legislative incidence of a tax (i.e., who is legally responsible for paying the tax) bears no relationship whatsoever to the economic incidence of a tax (i.e., who actually ends up bearing the burden of the tax once all price changes have taken place). In the Andy and Betty story, for instance, the legislative incidence of the seizure (Betty was the one robbed, strictly speaking, in both of the cases that we examined) bore no relationship at all to the economic incidence of the seizure (in the first case, Betty bore the entire burden; in the second case, the burden was split evenly between Andy and Betty). Moreover, the revenue derived from a tax by the state will also be invariant to its legislative incidence. Hence, the state should be indifferent (at least on efficiency grounds) to the legislative incidence of a tax, and we can therefore assume for the sake of convenience that the entire tax is formally levied on the buyer. Given this simplifying assumption, the statement in the text will be true.

${ }^{15}$ Jeremy Waldron, The Right to Private Property (New York: Oxford University Press, 1990), p. 404. 
entitled to any of the proceeds. Second, CSO prohibits forced labor, such as compulsory jury duty, military conscription, national service, corvée labor, "Good Samaritan" laws, and so on. Third, CSO comes extremely close to implying that individuals may consume narcotics, commit suicide, prostitute themselves, and engage in any form of (amateur) consensual sex imaginable. I say "extremely close" here because all of these activities require in addition the use of external resources--though in most or perhaps all of these cases even the most rudimentary use rights over external resources would be sufficient to get the job done. Support for all of these positions, incidentally, can be found in the writings of libertarians such as Robert Nozick and Murray Rothbard. ${ }^{16}$

Less obviously, CSO prohibits a particular species of taxation: namely, redistributive lump-sum taxation at a level that compels labor. ${ }^{17}$ A lump-sum tax is a "head" tax, that is, a tax that is fixed in size and therefore invariant to the behavior of the taxpayer. Margaret Thatcher's infamous poll tax, which led to rioting in London, is an example of such a tax. To see why a lump-sum tax might compel labor, we will need to introduce some notation. Consider a typical consumer's budget constraint, where $p_{i}$ is the price of private good $i, x_{i}$ is the quantity of good $i$ purchased, $w$ is the consumer's wage rate, $L$ is the amount of labor done by the consumer, $M$ is the consumer's lump-sum income (i.e., rental income-we will ignore gifts and other forms of lump-sum income for convenience), and $T$ is a lump-sum tax:

$$
\sum_{i} p_{i} x_{i}+T \leq w L+M
$$

In words, total expenditures (on private goods and lump-sum taxes) must be less than or equal to total revenues (from both labor and lump-sum income). Notice that if $T>M$, the consumer will be forced to work to pay the tax, even if he buys no private goods; this will occur when his rental income, either potential or realized, from physical assets (e.g., land or capital) fails to cover the lump-sum tax. ${ }^{18}$ Historically, governments have often

${ }^{16}$ On voluntary slavery and suicide, see Nozick, Anarchy, State, and Utopia, pp. 58, 331. On forced labor, see Rothbard, For a New Liberty, pp. 79-81, 89-90. On narcotics consumption and sex (both amateur and professional), see ibid., pp. 105-8, 111-12.

${ }^{17} \mathrm{Cf}$. Peter Vallentyne, who believes that a "wealth tax on the value of personal endowments [i.e., a lump-sum tax in excess of lump-sum income] ... is compatible with Control Self-Ownership": see "Self-Ownership and Equality: Brute Luck, Gifts, Universal Dominance, and Leximin," Ethics 107 (1997): 321-43, p. 325, which is a review of Philippe Van Parijs, Real Freedom for All (Oxford: Clarendon Press, 1995).

${ }^{18}$ I mention "potential" rental income to rule out those cases in which an individual could pay the lump-sum tax with nonlabor income but chooses not to do so. For example, 
literally compelled labor of those unable or unwilling to pay the tax (e.g., corvée labor). Even in the absence of actual labor compulsion, however, physical punishment (e.g., arrest and incarceration) will have to be imposed on those refusing to work, and such coercion obviously involves the violation of control rights over one's own body. ${ }^{19}$ To see this compulsion more clearly, compare the lump-sum tax just described to a proportional labor tax, in which the government gets a fraction of every dollar earned. With such a tax, an individual may work as little or as much as he wants; a refusal to work will trigger no physical compulsion by the state whatsoever.

It is often claimed that lump-sum taxation is an almost wholly premodern phenomenon, but urban slavery in the antebellum South frequently took a form reminiscent of lump-sum labor taxation. I quote from Richard Wade's definitive text on the subject:

The hiring-out system gave slavery the flexibility it required in the urban milieu ... Under this arrangement, masters told their Negroes to locate a job, make their own agreement on wages, and simply bring back a certain sum every week or month. The slave, moreover, could pocket any profit he made ... Often the owner did not know where his blacks worked; no contract bound master and employer; and no special public supervision governed the arrangement. "Hiring their own time," as this was called, brought the slave into a new relationship with his owner, more like that of tenant and landlord than bondage in the usual sense. Even this connection broke down in many instances when hirelings began to rent housing away from the old premises. ${ }^{20}$

A key difference between the two systems, of course, is that slaveowners could sell their right to this income stream, whereas government generally cannot sell its right to the income stream generated by lumpsum taxes (i.e., its right is inalienable). Thus, lump-sum redistributive labor taxation looks a great deal like a form of serfdom, a paradigmatically unfree form of labor. ${ }^{21}$ That libertarians would oppose this form of taxation is obvious, given their opposition to forced labor.

an owner-occupier of a home takes his rental income in the form of consumption, so to speak, by living in the house rather than renting it. If a lump-sum tax in an amount less than the potential rental income is imposed on such a person, it does not compel labor, because the owner could stop occupying the home, rent it, and use the income to cover the tax. Only when a lump-sum tax exhausts all sources of rental income, potential and realized, does it begin to compel labor.

${ }^{19} \mathrm{Clearly}$, the government cannot impose a fine as punishment: this would be equivalent to increasing the size of the lump-sum tax, which by assumption the individual can pay only by working - which is precisely what he is refusing to do.

${ }^{20}$ R.C. Wade, Slavery in the Cities: The South 1820-1860 (New York: Oxford University Press, 1964), p. 48; emphasis added.

${ }^{21}$ Hegel also associates such taxation with feudalism, saying that a just political order will instead allow a citizen's taxes "to be mediated through his own arbitrary will," which is what proportional labor taxation accomplishes. See his Philosophy of Right (London: Oxford University Press, 1967 [1821]), pp. 194-95. 
CSO is arguably the complete liberal conception of self-ownership. CSO is either explicitly or implicitly endorsed by John Christman, James Grünebaum, Andrew Kernohan, and Ronald Dworkin, and by John Rawls himself. ${ }^{22}$ At least historically, liberals have opposed most varieties of forced labor (e.g., slavery, serfdom, military conscription during peacetime, corvée labor, and so on), strongly supported a wide range of personal and civil liberties, and attacked guild monopolies and other feudal restrictions as inconsistent with open, competitive labor markets. At first glance, then, CSO and liberalism would appear to be a good match.

Liberals should be aware, however, of the potential costs of incorporating even such a modest version of self-ownership into their ideological framework. First, the incorporation of CSO might compel liberals to adopt "libertarian" positions on a whole host of personal liberty issues (including consensual sex and suicide; narcotics consumption and prostitution; and organ sales, indentured servitude, and voluntary slavery). Such adoptions would probably cause little discomfort for liberals on the first two issues, more substantial discomfort on the second two, and extreme discomfort on the last three. Unless some way can be found to overturn or at least soften the more radical implications of CSO, liberals will face the dilemma of either becoming more libertarian or dropping their support (whether explicit or implicit) for $\mathrm{CSO}$ - an option that may carry severe costs of its own, as we shall see in the conclusion to the paper.

Second, the incorporation of CSO might be inconsistent with liberalism's simultaneous commitment to both redistribution and government

${ }^{22}$ Christman, "Self-Ownership, Equality, and the Structure of Property Rights," p. 39; Grünebaum, Private Ownership (London: Routledge \& Kegan Paul, 1987), p. 171; Kernohan, "Rawls and the Collective Ownership of Natural Abilities," Canadian Journal of Philosophy 20 (1990): 19-28, p. 22; Dworkin, "In Defense of Equality," Social Philosophy and Policy 1 (1983): 24-40, p. 39; Rawls, "The Basic Liberties and Their Priority," in S.M. McMurrin (ed.), Liberty, Equality and the Law: Selected Tanner Lectures on Moral Philosophy (Salt Lake City: University of Utah Press, 1987), p. 50. Rawls's endorsement is the most oblique. In discussing "freedom of the person," he argues that it would be "violated, for example, by slavery and serfdom, and by the denial of freedom of movement and occupation" (ibid.). He seems to be concerned here primarily with an individual's control rights over his own person. Both Richard Arneson and Andrew Kernohan argue that this reading of Rawls is a plausible one; see Arneson, "Property Rights in Persons," Social Philosophy and Policy 9 (1992): 201-30, p. 211, and Kernohan, "Rawls and the Collective Ownership of Natural Abilities," pp. 21-22. Rawls is also opposed to lump-sum redistributive labor taxation, which he believes interferes with the basic liberties, as he notes in his "Reply to Alexander and Musgrave," Quarterly Journal of Economics 88 (1974): 633-55, p. 654. Although he does not spell out his reasons for this belief, one possible explanation is that labor compulsion on the model of serfdom would not be agreed to in the original position because of the "strains-of-commitment" concerns of agents, especially when alternative sources of revenue to support government activities are available (Theory, p. 176). 
neutrality with respect to the good. Richard Arneson persuasively argues that a belief that "the state in its redistributive activities ... should not discriminate [among individuals] simply because of different tastes for consumption goods, work, and leisure" implies that "in some circumstances, forced labor can be a morally acceptable state policy."23 Arneson may very well have given an informal proof of a new impossibility theorem in political theory; if so, liberals might have to decide which of these three commitments - CSO, redistribution, or government neutrality- to jettison. ${ }^{24}$

So far, I have not discussed possible moral justifications for CSO, which constitutes the core of libertarian self-ownership and the whole of liberal self-ownership. The simplest possible justification-and the one that probably motivates its adherents-is a desire to protect individual autonomy and, more narrowly, the inviolability of the person. This position is well expressed by John Christman:

What matters in self-ownership, I have suggested, is individual rights to control oneself to no intervention in use (of one's talents). The specific motivation behind self-ownership involves the strong interest that I have in running my own life. If the state or other entity tells me when and where I must utilize my abilities-forcing me to produce this or preventing me from producing that-something deep and fundamental is sacrificed. ${ }^{25}$

Of course, inviolability of the person is not a sufficient condition for autonomy so understood: without access to external resources, control over one's own life may be difficult or impossible, even if CSO is protected-a fact that prompts left-libertarian support for ensuring such access to all people. Apart from its connection to autonomy, are there other justificatory grounds for CSO? One approach, which I have developed elsewhere, is to determine whether the correlative duty to the right of exclusion (the duty of physical noninterference) can be justified on Kant-

\footnotetext{
${ }^{23}$ Arneson, "Property Rights in Persons," pp. 204-5. Arneson asks us to imagine two high-ability people who are identical in every way except for their conceptions of the good, which are radically different. Let us make one a La Jolla surfer who communes with waves, begs for food, and sleeps on the beach; let us make the other a conspicuousconsumption yuppie who works 100 hours per week so that he can fill his three-car garage with BMWs. Without redistributive lump-sum taxes and the labor compulsion they provide, the surfer will contribute absolutely nothing to the War on Poverty, whereas the yuppie will be forking over a hefty portion of his income to the fight. To Arneson, this differential treatment does not seem consistent with government neutrality with respect to the good (less exotically known to public-finance economists as horizontal equity): why should money-lovers be taxed more heavily than leisure-lovers?

${ }^{24}$ Those readers who suspect that labor compulsion for purposes of redistribution is of merely theoretical interest should keep in mind that European countries with military conscription often have alternative "civilian service" programs of a redistributive nature (e.g., serving as teachers in impoverished areas).

${ }^{25}$ Christman, "Self-Ownership, Equality, and the Structure of Property Rights," p. 39.
} 
ian grounds. If so, CSO itself can be given a Kantian justification, given the central explanatory role the right of exclusion plays with respect to the other control incidents. ${ }^{26}$ Whichever justificatory approach one favors, the widespread belief that bodily violation is a special category of wrong explains the strong attraction of both liberals and libertarians to a concept that categorically denies the justice of such aggressive behavior.

\section{b. The extended conception: libertarian self-ownership}

On the subject of income rights, libertarians and liberals part ways. Libertarians correctly view an untrammeled right to labor income to be an ineliminable component of their conception of self-ownership. Such a right, after all, directly implies that redistributive labor taxation (be it proportional or otherwise) is unjust, which is precisely the policy conclusion that the libertarians want-and that the liberals most want to avoid. This explains why so much ink has been spilled by both sides over the issue of whether to include the right to labor income as an incident of self-ownership.

If you recall the analysis of section 2 , you will immediately see the challenge for libertarians: there does not appear to be the right kind of link between control rights (which are admitted by both sides to be morally desirable components of self-ownership) and the right to income. Libertarians often assume the existence of such a link in their arguments with liberals over the morality of redistributive labor taxation. Consider, for instance, the following argument by Nozick against Rawls's Difference Principle:

An application of the principle of maximizing the position of the worst off might well involve forcible redistribution of bodily parts ("You've been sighted for all these years; now one-or even both-of your eyes is to be transplanted to others"), or killing some people early to use their bodies in order to provide material necessary to save the lives of those who otherwise would die young. ${ }^{27}$

This argument draws its power from an unstated assumption: that control rights over one's body and a right to one's labor income are of a piece, so that collectivization of the latter automatically threatens the former. ${ }^{28} \mathrm{As}$

\footnotetext{
${ }^{26}$ I offer two explicitly Kantian defenses of CSO in "A Kantian Defense of SelfOwnership," The Journal of Political Philosophy 12 (2004): 65-78. One shows that maxims contrary to CSO (such as maxims of exploitative or paternalistic physical aggression) cannot be universalized, while the other argues that such maxims involve a profound status wrong-namely, treating rational agents as animals or children-and that such a system of differential status can be justified by looking to man's nature as a self-legislating being.

${ }^{27}$ Nozick, Anarchy, State, and Utopia, p. 206.

${ }^{28}$ In $A$ Theory of Justice, Rawls asserts that "the difference principle represents, in
} 
we have seen, though, there is really no direct connection between the two: the right to one's labor income is derived from the (monetary) transfer powers of other people, not one's own transfer powers.

Not surprisingly, then, a standard libertarian tactic has been to attempt to forge indirect links between these rights. If this approach were successful, libertarians would actually stand some chance of converting hordes of liberals to their cause-a seemingly irresistible prize. In what follows, I will examine and evaluate two such attempts to forge indirect links between the control rights and the right to income: the Slavery Argument and the Argument from Value.

1. The Slavery Argument. Libertarians have often set back their own cause by attempting to link these rights in ways that are clearly implausible. For instance, I noted earlier that Nozick and Rothbard refer to redistributive labor taxation as a form of "forced labor" and "involuntary servitude," respectively. ${ }^{29}$ This approach does not seem a particularly promising one; moreover, it dangerously cheapens the meaning of the term "forced labor." We have already seen that one form of redistributive labor taxation-specifically, lump-sum taxation in excess of lump-sum income-genuinely compels labor and therefore violates CSO. However, such taxation as it is usually practiced is not compulsive: under a system of proportional labor taxation, for example, individuals may work as litthe or as much as they want at any job they choose; they may even remain completely idle. The government only claims a fraction of any labor income they choose to generate. Such taxation might be unwise or even unjust, but it hardly qualifies as forced labor.

A slightly more promising approach (though still tainted by association with the previous one) is Nozick's so-called "Tale of the Slave," a story that is based upon a similar argument by Herbert Spencer. ${ }^{30}$ In order to move us expeditiously to Nozick and Spencer's main point, I will present a shorter, modified version of their argument. Imagine that in the antebellum South, slaveowners had all gathered together and decided to abolish the institution of slavery. However, suppose that, in order to provide some compensation to themselves for their loss of "capital," they had decided upon the following scheme of emancipation: slaves would all become free citizens, but for the rest of their lives they would owe a certain percentage

effect, an agreement to regard the distribution of natural talents as a common asset" ( $p$. 102). This statement causes Nozick much anxiety, an anxiety that can be readily explained by his conflation of control rights and income rights (Anarchy, State, and Utopia, p. 228).

${ }^{29}$ Ibid., p. 169; Rothbard, For a New Liberty, p. 85.

${ }^{30}$ Nozick, Anarchy, State, and Utopia, pp. 290-92; Herbert Spencer, The Man Versus the State (Indianapolis: Liberty Classics, 1981 [1884]), pp. 55-57. 
of their labor income (say, 25 percent) to their former owners. Would such a system still be morally tainted? Few would hesitate to say yes. ${ }^{31}$

Now Nozick and Spencer (in effect) ask us to do the following: replace the word "slaves" with "the rich" or "the talented," and replace the word "slaveowners" with "the poor" or "the disabled." Now they ask again: would this system be morally tainted? Unfortunately for Nozick and Spencer, most people would probably answer no, and many people would even be deeply offended by the question itself. The injustice of the first system, after all, derives not from its redistributive nature per se but rather from the direction of the redistribution, from former slaves to their erstwhile owners. Had we reversed the direction of the redistribution in the first system, no doubt most people would have cheerfully endorsed it. This observation helps explain why Nozick and Spencer's analogy fails so miserably.

Still, there is something slightly disconcerting about the fact that under a system of proportional, redistributive labor taxation, individuals are merely "majority shareholders in themselves," to use Michael Gorr's provocative image - with the minority shareholder, of course, being the state. ${ }^{32}$ Each individual's majority status with respect to his own person (which has been "incorporated") guarantees that he will retain control of himself and that only he will make the managerial decisions concerning his own life and fate. The state, however, will claim a percentage of his labor income that is proportional to the number of shares it holds and will use this income to subsidize those individuals whose shares are less valuable (due to their lower productivity, perhaps).

If we accept Gorr's "corporate" metaphor at face value, then the state's minority status would seem to imply that it has an ownership right over a private person. Libertarians find this kind of ownership to be particularly offensive, at least when the person in question has not agreed to transfer the relevant rights to the state. On this point Nozick writes:

End-state and most patterned principles of distributive justice [implemented by redistributive labor taxation] institute (partial) ownership by others of people and their actions and labor. These principles involve a shift from the classical liberals' notion of selfownership to a notion of (partial) property rights in other people. ${ }^{33}$

Note two things about this argument, however. First, it simply assumes

\footnotetext{
${ }^{31}$ Interestingly, many of the nations that managed to abolish slavery without a civil war provided compensation to former slaveowners - though usually in the form of a lump-sum payment out of general tax revenues.

${ }^{32}$ Michael Gorr, "Justice, Self-Ownership, and Natural Assets," Social Philosophy and Policy 12 (1995): 267-91, p. 271; emphasis added.

${ }^{33}$ Nozick, Anarchy, State, and Utopia, p. 172.
} 
what needs to be proven: namely, that the income right originally inheres in the person rather than in the state or some other entity. As we have already shown, there is no direct way to connect CSO and the right to labor income, and the mere presentation of an admittedly powerful metaphor is insufficient to establish this connection. Second, even if we were to accept the connection, the success of this argument would still hinge on the nonconsensual nature of the state's (partial) ownership claim. Libertarians, to make this argument more convincing, would need to show why people would not consent to such a transfer of income rights to the state under the appropriate conditions, that is, they would need to engage in social-contract theorizing. ${ }^{34}$ If these two objections could be met, this argument might generate the requisite link between CSO and the right to labor income, thereby buttressing the libertarian argument against redistributive labor taxation.

2. The Argument from Value. Besides Gorr's "corporate" analogy, another approach available to libertarians for tying control rights and the right to income more tightly together is to point out that while the right to income might not be directly implied by one's own power of transfer, it does underwrite the value of that power. This strategy seems more promising, as the suggested connection is indeed a strong one. There is something very attractive, after all, about the idea that we should be concerned not merely with the protection of incidents of ownership, but also with the protection of their value to those who hold them.

Consider, for instance, the case of a talented pianist whose services are much in demand. Although a confiscatory (i.e., 100 percent) tax on the pianist's earnings would not, strictly speaking, violate the pianist's power of transfer (he would still be able to give away his services), it would dramatically reduce the value of that power-in fact, it would virtually extinguish it (unless, of course, the pianist took great pleasure in giving free concerts). The confiscatory tax, in terms of its effect on the value of the transfer power, does nearly as much damage as the elimina-

\footnotetext{
${ }^{34}$ See, e.g., the works of James Buchanan, Ken Binmore, David Gauthier, and Gregory Kavka, who have resurrected and formalized a Hobbesian brand of social-contract theory, sometimes with libertarian results. Relevant texts include Buchanan, The Limits of Liberty: Between Anarchy and Leviathan (Chicago: University of Chicago Press, 1975); Binmore, Game Theory and the Social Contract (Cambridge, Mass.: MIT Press, 1994); Gauthier, Morals by Agreement (Oxford: Clarendon Press, 1986); and Kavka, Hobbesian Moral and Political Theory (Princeton: Princeton University Press, 1986). As noted above, it would be difficult to make such a social-contract argument for redistributive lump-sum taxation, at least in a Rawlsian framework, due to strains of commitment: agents in the original position would hesitate to allow a form of taxation tantamount to serfdom given the psychological burden involved in obedience to it and the consequent likelihood of resistance.
} 
tion of the power itself would do.

The neatness of this solution may seem too good to be true. Up until this point, I have focused on only one of the problems libertarians must confront in constructing their conception of self-ownership: namely, getting CSO and the right to labor income to cohere. Now another, quite different, problem presents itself: preventing rights that are anathema to libertarians from adhering to their preferred conception of selfownership. The dilemma that libertarians face with the argument from value is that although it supports the incorporation of an income right, it also acts like a miniature black hole, drawing in rights indiscriminatelyincluding rights that libertarians would like to keep out.

Consider, for example, the following quotation from Michael Otsuka: "[t]he worth of one's right of self-ownership ... normally increases with increases in the extent of one's rights over worldly resources [i.e., nonhuman resources: land and capital]., ${ }^{35}$ With more worldly resources, the disgruntled factory worker who loathes every hour of his labor on the assembly line might be able to set up shop as an independent artisan, selfdirected and happy at his work, a satisfied member of the petite bourgeoisie. Would this not increase the value of his labor, at least to himself? Libertarians, however, have something of an ideological distaste for redistributing worldly resources. As Nozick would say, "things come into the world already attached to people having entitlements over them.,36

Of course, left-libertarians such as Steiner, Otsuka, and Vallentyne might just chuckle contentedly at such a development and point out that they would be quite happy to take on board an additional right (to nonhuman-resource access), so long as the control rights and the right to income continue to be protected. But even these rights, it turns out, are not safe from the vortex of the argument from value. In a passage that expresses much the same sentiment as the factory-worker example above, G.A. Cohen makes the following assertion:

There is good reason to suppose that, at least in a world of people with different measures of talent, self-ownership is hostile to autonomy, for, in such a world ... the self-seeking authorized by self-ownership generates propertyless proletarians whose life prospects are too confined for them to enjoy the control of a substantial kind over their lives that answers to the idea of autonomy. Accordingly, if everyone is to enjoy a reasonable degree of autonomy, it is necessary, at least in some circumstances, to impose restrictions on self-ownership. ${ }^{37}$

${ }^{35}$ Michael Otsuka, "Self-Ownership and Equality: A Lockean Reconciliation," Philosophy and Public Affairs 27 (1998): 65-92, p. 84. A somewhat related observation is made by Hegel, who considers private-property ownership to be essential to the development of personhood (Philosophy of Right, pp. 42, 236).

${ }^{36}$ Nozick, Anarchy, State, and Utopia, p. 160.

${ }^{37}$ G.A. Cohen, Self-Ownership, Freedom, and Equality (New York: Cambridge Uni- 
This passage suggests that once we start concerning ourselves with the value that incidents of ownership have to individuals (for instance, in their ability to enhance autonomy), we must eventually face the question of how value is to be distributed across individuals. In other words, concern for the value of rights may lead us unwittingly toward a utilitarianism of rights. Consider: imposing a redistributive tax on the labor income of the talented will certainly reduce the value of their transfer powers, but if that tax revenue is directed to the needy it will increase the value of their control incidents for the same reason that enhanced resource access did. As Cohen suggests, might not this trade-off be worthwhile under some circumstances?

The point of this somewhat belabored argument is to suggest that a concern for the value of rights may do much more work than libertarians of any variety want done. Some readers may find it absurd that a theory of rights would have to disregard the value of the rights it advocates to preserve itself, but libertarianism is not unique in this regard. For example, if we repeat the argument of the last paragraph with a lump-sum tax instead, we will find that even CSO (and, by implication, CSO-endorsing liberalism) is vulnerable. ${ }^{38}$

\section{Conclusion}

As we have seen, libertarians face a daunting challenge in getting the various components of their conception of self-ownership to cohere. As I demonstrated in section 2, a right to labor income cannot be directly derived from the more fundamental incidents of CSO. I then showed in section 3 that two strategies for connecting these incidents indirectly (the Slavery Argument and the Argument from Value) are not particularly fruitful. Unless libertarians can find another way to link these two kinds of rights, their arguments against redistributive labor taxation will prove unconvincing to others, especially liberals.

Despite the paper's generally discouraging tone, libertarians can take comfort in at least two of its findings. ${ }^{39}$ First, Gorr's "corporate" anal-

versity Press, 1997), p. 237; emphasis added.

${ }^{38}$ This subsection presents a version of what moral philosophers call the "paradox of rights." For a more detailed discussion of this paradox, see several of the contributions to Samuel Scheffler (ed.), Consequentialism and Its Critics (Oxford: Oxford University Press, 1988), especially Scheffler's own ("Agent-Centered Restrictions, Rationality, and the Virtues," pp. 243-60).

${ }^{39}$ Libertarians should also note that this paper's argument does nothing to overturn consequentialist arguments against redistribution, e.g., that high levels of redistribution may so cripple efficiency that even the poor will suffer or that state efforts to redistribute 
ogy, which suggests that individuals subjected to redistributive labor taxation are merely "majority shareholders" in themselves, does nicely capture the moral intuition behind libertarian opposition to redistributive labor taxation. Gorr's imagery seems quite powerful, suggesting that there may be some (yet undiscovered) animating moral principle behind it that could provide the needed link between control rights and the right to income. The other possibility, of course, is that no such principle exists and that the moral intuition of libertarians should be revised in light of this fact. ${ }^{40}$ Given what is at stake, however, libertarians should be well motivated to continue the search.

Second, as I noted earlier, liberals' flirtation with CSO exposes them to certain ideological hazards. The incorporation of such a principle into their theory might, for example, necessitate the adoption of controversial libertarian positions on a host of personal liberty issues. It might also compel a reconsideration of other principles that liberals cherish, such as government neutrality with respect to the good. Liberals could respond to these potential hazards by simply rejecting CSO outright, but such a decision would likely have costs of its own. After all, liberals' interest in self-ownership was initially motivated by the realization that their resource egalitarianism, in the absence of side-constraints such as selfownership, might generate moral horrors such as compulsory organ harvesting. ${ }^{41}$ In short, liberals would appear to be trapped between a Scylla of moral horrors and a Charybdis of ideological incoherence-which is precisely where libertarians would like them to be. ${ }^{42}$

Robert S. Taylor Department of Political Science University of California, Davis rstaylor@ucdavis.edu

income may primarily benefit the politically powerful at the expense of the poor.

${ }^{40}$ This hopefully convergent process of revising considered judgments in light of principles and revising principles (and the justificatory processes by which they are generated) in light of considered judgments is described by John Rawls in the "reflective equilibrium" passage of Theory (p. 48).

${ }^{41}$ Will Kymlicka, Contemporary Political Philosophy (New York: Oxford University Press, 1990), pp. 152-55.

${ }^{42}$ Earlier versions of this paper were presented at the University of California, Berkeley, and at the 2001 Annual Meeting of the American Political Science Association. I wish to thank in particular Peter Vallentyne, Chris Kutz, Shannon Stimson, Robert deNeufville, and Robert Adcock for their helpful comments and suggestions. 
Copyright of Social Theory \& Practice is the property of Florida State University / Dept. of Philosophy. The copyright in an individual article may be maintained by the author in certain cases. Content may not be copied or emailed to multiple sites or posted to a listserv without the copyright holder's express written permission. However, users may print, download, or email articles for individual use. 